\title{
PROMĚNY KONSTRUKTIVISMU V MUZEJNÍ PEDAGOGICE GEORGE E. HEINA
}

MONIKA MIKULÁŠKOVÁ

\section{ABSTRAKT/ABSTRACT:}

Pedagogické teorie v současnosti pronikají i mimo tradiční instituci školy a rozvíjejí se i v těchto netypických prostř̌edích. Takovým prostředím je i muzeum. To, co začalo jako pouhá snaha o implementaci teorie do svébytné praxe, se nakonec stalo novou bází, na které se teorie může samostatně rozvíjet a zpětně znovu ovlivnit hlavní pedagogický diskurz. V následující studii popisujeme jeden $\mathrm{z}$ prrípadů, kdy došlo k významnému posunu pedagogické teorie, zde konstruktivistické, $\mathrm{v}$ prostředí muzea a muzejní pedagogiky. George E. Hein patří mezi nejvýznamnější muzejní pedagogy současnosti a jeho práce je kvitována $v$ muzejně pedagogickém diskurzu po celém světě. Hlavním cílem předloženého textu je tedy prokázat a popsat význam výzkumů a teoretického uvažování na poli muzejní pedagogiky pro obecný pedagogický diskurz na př́kladu konstruktivismem zabývajících se textů G. E. Heina.

\section{Transformations of \\ Constructivism in Museum Pedagogy of George E. Hein}

At present, pedagogical theories are moving beyond traditional school institutions and develop in unconventional environments. The museum is one of them. What started as an effort to implement theory into practice finally gave rise to a novel base on which theory can evolve independently, and can also influence the main pedagogical discourse.
https://doi.org/10.5817/MuB2017-1-5
This study describes one of the cases in which a major shift in the pedagogical theory occurred, in this particular case the constructivist theory, in the environment of the museum and museum pedagogy. George E. Hein counts among leading museum educators of the present and his works are acknowledged in the museum pedagogy discourse all over the world.

This paper seeks to demonstrate and describe the importance of research and theoretical thinking in the field of museum pedagogy for the general pedagogical discourse on the example of G. E. Hein's articles devoted to constructivism.

\section{KLIIČOVÁ SLOVA/KEY WORDS:}

pedagogická teorie - pedagogický konstruktivismus - muzejní pedagogika - teorie učení - teorie poznání pedagogical theory - pedagogical constructivism - museum pedagogy theory of learning - cognitive theory

\section{ÚVODEM $^{1}$}

Postavení muzejní pedagogiky v systému věd není jasné. Jůva ji chápe jako sociální vědu zabývající se muzejní edukací ${ }^{2}$ (muzejní edukací je míněno „zámérné, facilitované a intencionální působení

1 Předkládaný text původně vychází z ročníkové práce vzniklé během studia pedagogiky na FF MU. 2 JAGOŠOVÁ, Lucie, Vladimír JŮVA a Lenka MRÁZOVÁ. Muzejní pedagogika: metodologické a didaktické aspekty muzejní edukace. Brno: Paido, 2010, s. 80. muzea na veřejnost ${ }^{\text {()), }}{ }^{3}$ Stránský jako specializovanou integrovanou muzeologii (tedy jako aplikaci poznatků jiné vědní disciplíny dotýkající se muzealizace). ${ }^{4}$ Podstatné je, že předmětem muzejní pedagogiky je muzejní edukace, $\mathrm{k}$ jejímuž zkoumání je využívána řada metod čerpaných jak z různých oblastí pedagogiky (např. pedagogika volného času, andragogika, pedagogika zážitku), muzeologie (v muzeu edukujeme na základě poznání muzeality předmětů) ${ }^{5}$ či jiných věd (např. kulturální studia nebo psychologie).

Jak vyplývá z řečeného, můžeme si být jisti tím, že muzejní pedagogika je oborem interdisciplinárním a přejímání poznatků z dalších oborů se jeví jako nezbytné. Nicméně muzejní pedagogika představuje významného přispěvatele $k$ teoretickému uvažování o výchově a vzdělávání, jež má potenciál zasáhnout i obecný pedagogický diskurz, at už je vztah mezi pedagogikou a muzejní pedagogikou jakýkoli.

\section{Heinovi předchůdci a inspirační zdroje}

Průcha a kol. ve svém pedagogickém slovníku definují konstruktivismus jako ,... široký proud teorií ve vědách o chování a sociálních

\footnotetext{
3 ŠOBÁŇOVÁ, Petra. Edukační potenciál muzea. Olomouc: Univerzita Palackého v Olomouci, 2012, s. 219.

4 Oproti specializovaným konkrétním muzeologiím, kdy na základě spojení poznatků dvou věd vzniká nový obor. STRÁNSKÝ, Zbyněk. Úvod do studia muzeologie. Brno: Masarykova univerzita, 2000, s. 78-79.

5 ŠOBÁŇOVÁ, Petra. Edukační potenciál muzea. Olomouc: Univerzita Palackého v Olomouci, 2012, s. 223.
} 
vědách, zdůrazňujicí jak aktivní úlohu subjektu a význam jeho vnitřrních predpokladi̊ $v$ pedagogických a psychologických procesech, tak důležitost jeho interakce s prostředím a společností."“6

Konstruktivistické teorie také mohou být označovány jako teorie kognitivně psychologické. Bertrand je definuje takto: „Kognitivně psychologické teorie studují u žáka rozvoj takových kognitivních procesů, jako jsou usuzování, analýza, řešení problémů, vytváření reprezentací, prekonceptů, mentálních obrazů atd. " ${ }^{\text {7 }}$ Bertrand také zdůrazňuje dvě hlavní tendence, jež se v konstruktivistických teoriích uplatňují. Jedná se „o teorie, které se týkají prekonceptů žáka (konstruktivistické didaktiky) a teorie, které pojednávají o pedagogickém profilu žáka."8 Průcha a kol. rozlišují kognitivní konstruktivismus a sociální konstruktivismus, přičemž kognitivní tendence vycházejí zejména z prací Piageta a Brunera a sociální z prací Vygotského a Bandury. Kognitivní konstruktivismus se zaměřuje na „... didaktické postupy založené na predpokladu, že poznávání se děje konstruováním tak, že si poznávající subjekt spojuje fragmenty informací z vnějšího prostréedí do smysluplných struktur a provádí s nimi mentální operace podmíněné odpovídající úrovni jeho kognitivního vývoje."9 Sociální konstruktivismus „zdůrazňuje nezastupitelnou roli sociální interakce a kultury $v$ procesu konstrukce poznání, $v$ didaktice se jeho zásady realizují zejména $v$ kooperativním učení."

\footnotetext{
6 PRŮCHA, Jan, Jiří MAREŠ a Eliška

WALTEROVÁ. Pedagogický slovník. 2. rozš.

a přeprac. vyd. Praha: Portál, 1998, s. 113.

7 BERTRAND, Yves. Soudobé teorie vzdělávání. Praha: Portál, 1998, s. 17.

8 BERTRAND, Yves. Soudobé teorie vzdělávání. Praha: Portál, 1998, s. 65.

9 PRŮCHA, Jan, Jiří MAREŠ a Eliška WALTEROVÁ. Pedagogický slovník. 2. rozš. a přeprac. vyd. Praha: Portál, 1998, s. 113 10 Ibidem.
}

V článku z roku 1991 odpovídá Hein na otázku, co je to konstruktivismus takto: „Pojem se vztahuje $k$ ideji, že učící se jedinci pro sebe konstruují poznání - každý učící se jedinec tak individuálně (a společensky) konstruuje význam $v$ průběhu učení." ${ }^{11}$ A zároveň uvádí, že dopad tohoto přesvědčení se projeví především tím, že pedagogové se musejí zaměřit na učícího se jedince (nikoliv na obsah) a dále je třeba si uvědomit, že neexistuje žádné poznání (neexistují žádné znalosti), jež by bylo nezávislé (nekonstruované) na učícím se jedinci či skupině jedinců. ${ }^{12}$ Můžeme si tedy všimnout, že první definice tohoto autora $\mathrm{v}$ sobě zahrnuje specifikaci kognitivního konstruktivismu.

V následujících článcích propracovává Hein definici konstruktivismu na základě vztahu $\mathrm{k}$ teorii poznání a učení, jak bylo uvedeno $\mathrm{v}$ předchozí kapitole, konkrétně uvádí: „Konstruktivismus tvrdí, že poznání i způsob, jakým je získáváno, závisí na mysli učicího se jedince. " ${ }^{13}$ Dále zdůrazňuje, že učící se jedinec pouze nepřidává nové poznatky $\mathrm{k}$ těm předcházejícím, ale neustále reorganizuje a vytváří zároveň porozumění a prohlubuje své schopnosti učit se sociální interakcí. ${ }^{14}$ Zde je tedy definice rozšířena takovým způsobem, který zahrnuje i tendence spojované se sociálním konstruktivismem. Jak uvádí Průcha a kol., propojování kognitivního a sociálního konstruktivismu je v praxi běžné. ${ }^{15}$ Švaříček

\footnotetext{
11 HEIN, George E. Constructivist Learning Theory (CECA Conference: The Museum and the Needs of People, 15-22 October 1991, Jerusalem, Israel). In Exploratorium. Institute for Inquiry [online]. [cit. 2017-06-20]. Dostupný z www: $<$ https://www.exploratorium.edu/education/ifi/ constructivist-learning > P Príspěvek na konferenci. 12 Ibidem.

13 HEIN, George E. The Constructivist museum. (Journal for Education in Museums, 1995, no. 16, s. 21-23). In Group of Education in Museums [online]. 1995 [cit. 2017-06-20]. Dostupný z www: <http://www.gem.org.uk/pubs/news/hein1995. php>.

14 Ibidem.

15 PRŮCHA, Jan, Jiří MAREŠ a Eliška WALTEROVÁ. Pedagogický slovník. 2. rozš.
}

a Šed’ová uvádějí, že „koncept konstruktivismu se vztahuje $k$ vytváření významů a pojmů $v$ mysli jedince a vyjadřuje jedinečnou zkušenost každého člověka a pohliží na ni jako na svébytný způsob vztahování se ke světu. "16 Při porovnání s Heinovými texty si můžeme všimnout, že autor zahrnuje vytváření významů do centra uvažování o konstruktivismu a píše: „Konstruktivismus je pedagogická teorie, která zároveň uznává význam individuálního vytváření významů a činí jej centrálním aspektem pedagogické praxe. ${ }^{\text {"17 }}$

Po specifikaci Heinova př́istupu dle základní terminologie se zaměříme na konkrétní inspirační zdroje, které autor do své teorie zapracovává. Jak bylo naznačeno výše, Hein od konstruktivistické teorie postupuje $\mathrm{k}$ systematizaci všech pedagogických teorií a zkoumá dopad těchto teorií na muzejní pedagogiku.

V rámci uvažování o didaktické a výkladové edukaci Hein opakovaně cituje zástupce technologických pedagogických teorií Roberta Gagného. ${ }^{18}$ Technologické teorie „zdưrazňují zdokonalení předávání informací použitím vhodných technologii. “"19 Hein se zde věnuje těm Gagného tezím, jež se zaměřují na vytváření systému, jímž lze optimálně předávat poznatky. Tento přístup se poté v muzejní edukaci realizuje výstavami či expozicemi s jasně vytyčeným cílem i průběhem, edukačními programy strukturovanými od jednoduchých poznatků ke komplexnějším, programy nava-

\footnotetext{
a přeprac. vyd. Praha: Portál, 1998, s. 113. 16 ŠVAŘíČEK, Roman a Klára ŠEĎOVÁ. Konstruktivismus v e-learningové vysokoškolské výuce? (Constructivism in E-learning at University-Level Teaching?). In Sborník prací filozofické fakulty brněnské univerzity. U12. Brno: Masarykova univerzita, 2007, s. 190.

17 HEIN, George E. Is Meaning Making constructivism? Is Constructivism Meaning making? The Exhibionist, 1999, roč. 18, č. 2, s. 16.

18 HEIN, George E. Learning in the museum. London: Routledge, 1998, s. 15-30.

19 BERTRAND, Yves. Soudobé teorie vzdělávání. Praha: Portál, 1998, s. 17.
} 
zují na oficiální kurikulum. ${ }^{20}$ Hein upozorňuje, že tento přístup, který se orientuje na obsah učení, může vyhovovat pouze některým učícím se jedincům, $u$ jiných může naopak přijímání informací dokonce stěžovat. ${ }^{21}$ Spojení muzejní pedagogiky a technologických pedagogických teorií je velmi logický krok z toho pohledu, že muzea využívají k edukaci neživého prostředníka média výstavy či expozice, stejně jako technologické teorie, které se typicky zaměřují na učení skrze média, jako jsou počítačové programy, videozáznamy či zvukové záznamy. ${ }^{22}$

Ačkoliv se ve svém uvažování Hein obrací $\mathrm{k}$ mnoha různým autoritám pedagogických teorií, at’ už mluvíme o Freirem, Vygotském či Piagetovi, v jeho textech se s narůstající intenzitou setkáváme s dílem Johna Deweyho. Deweyho práce, stejně jako ta Freireho, bývá řazena k pedagogickým teoriím sociálním. Sociální teorie se odvíjí od přesvědčení, že „vzdělání má umožnit řešení problémů sociálních a kulturních i problémů životního prostředí...posláním vzdělávání je př́prava žáků na řešení těchto problémů." ${ }^{23} \mathrm{U}$ Freireho se Hein zaměřuje zejména na jeho myšlenky o kritickém vědomí, tedy že poznání vede $\mathrm{k}$ akci. Deweyho nejen pedagogickými myšlenkami se Hein zabývá i v současnosti, ${ }^{24} \mathrm{v}$ textech zde předložených pracuje zejména s Deweyho myšlenkou, že ne všechny zkušenosti, které působí na jedince, jedince vychovávají či vzdělávají, a tuto

\footnotetext{
20 HEIN, George E. Learning in the museum. London: Routledge, 1998, s. 20-25.

21 HEIN, George E. Is Meaning Making constructivism? Is Constructivism Meaning making? The Exhibionist, 1999, roč. 18, č. 2, s. 15-18.

22 BERTRAND, Yves. Soudobé teorie vzdělávání. Praha: Portál, 1998, s. 89-93.

23 BERTRAND, Yves. Soudobé teorie vzdělávání. Praha: Portál, 1998, s. 18-19.

24 Viz HEIN, George E. Progressive museum practice: John Dewey and democracy. Walnut Creek, Calif.: Left Coast Press, 2012.
}

$$
\begin{gathered}
\text { Učení je postupné } \\
\text { přidávání na tabula } \\
\text { rasa. }
\end{gathered}
$$

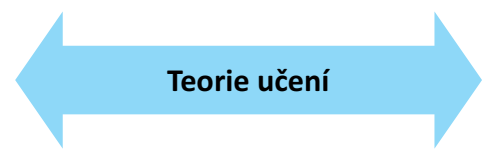

Učení je konstruování významů.

\author{
Poznání existuje \\ nezávisle na učícím se \\ subjektu.
}

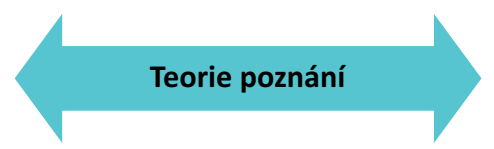

Poznání existuje pouze v mysli učícího se subjektu, je jím konstruováno.

Hein, 1995

Obr. 1: Teorie učení a teorie poznání

myšlenku aplikuje na zkušenosti získané návštěvou muzea.

\section{Proměny v Heinově díle o kon- struktivismu v letech 1991-2001}

Prvotní stadium Heinova uvažování si můžeme demonstrovat na příspěvku, který přednesl na konferenci CECA v Jeruzalémě. ${ }^{25}$ Cílem tohoto příspěvku bylo představit konstruktivistickou teorii a identifikovat její význam pro muzejní pedagogy. Autor předkládá základní definice konstruktivismu, vysvětluje, jaký dopad na praxi může mít, pokud se muzejní pedagog rozhodne pracovat podle konstruktivistické teorie. Významným momentem je definování devíti základních principů konstruktivismu:

1. učení je aktivní proces;

2. lidé se učí, jak se učit, když se učí;

3. zásadní procesy probíhají v mysli subjektu;

4. učení zahrnuje jazyk - jazyk, který se používá, ovlivňuje proces učení;

5. učení je sociální;

6. učení je kontextuální;

7. lidé potřebují mít nějaké předchozí znalosti, aby se mohli dále učit;

8. učení vyžaduje čas;

9. motivace je při učení klíčová.

25 HEIN, George E. Constructivist Learning Theory (CECA Conference: The Museum and the Needs of People, 15-22 October 1991, Jerusalem, Israel). In Exploratorium. Institute for Inquiry [online]. [cit. 2017-06-20]. Dostupný z www: $<$ https://www.exploratorium.edu/education/ifi/ constructivist-learning $>$. Příspěvek na konferenci.
Autor také upozorňuje, že je třeba přemýšlet o vztahu teorie učení a teorie poznáni. ${ }^{26}$ Dále však tyto termíny neupřesňuje a ani se vztahem mezi nimi v tomto článku nezabývá.

O čtyři roky později ve svém člán$\mathrm{ku} \mathrm{v}$ Journal for Education in Museums již představuje celistvější a propracovanější koncept. ${ }^{27}$ Teorie učení a teorie poznání označuje autor jako hlavní elementy každé pedagogické teorie. Oba tyto elementy autor vymezuje jako škálu přesvědčení, jež směřuje od jednoho extrémního pólu $\mathrm{k}$ druhému. U teorie poznání (epistemologie) představují tyto extrémní pozice tvrzení (1) poznání existuje nezávisle na učícím se subjektu a (2) poznání existuje pouze $v$ mysli učíciho se subjektu, je jím konstruováno. Teorie učení se poté pohybují mezi pozicemi (1) učení je postupné přidávání na tabula rasa a (2) učení je konstruování významů (viz obr. 1).

Pokud tyto dvě škály propojíme, získáváme sestavu čtyř hlavních skupin pedagogických teorií. Tyto skupiny pojmenovává učení objevováním, behavioristické učení, konstruktivismus a tradiční přednáška a text. Každá z těchto skupin je vždy určována postojem k teorii učení a postojem k teorii poznání.

\footnotetext{
$26 \mathrm{~V}$ originále theory of learning a theory of knowledge.

27 HEIN, George E. The Constructivist museum. (Journal for Education in Museums, 1995, no. 16, s. 21-23). In Group of Education in Museums [online]. 1995 [cit. 2017-06-20]. Dostupný z www: $<$ http://www.gem.org.uk/pubs/news/hein1995. php $>$.
} 
Definice vytváření významu

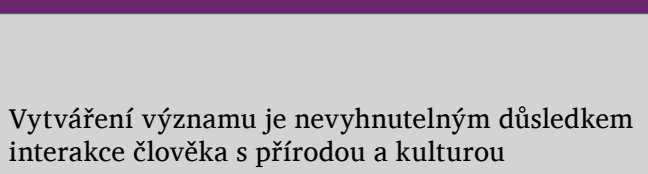

Vytváření významu je nevyhnutelným důsledkem interakce člověka s přírodou a kulturou

\begin{tabular}{|l|l|}
\hline Ignorují nebo potlačují & Tradiční, zaměřené na obsah \\
\hline Tolerují nebo akceptují & $\begin{array}{l}\text { Učení objevování, aktivní učení, teorie orientované } \\
\text { na učícího se jedince }\end{array}$ \\
\hline Podporují nebo zahrnují & Konstruktivismus \\
\hline
\end{tabular}

Tab. 1: Vytváření významů a pedagogické teorie

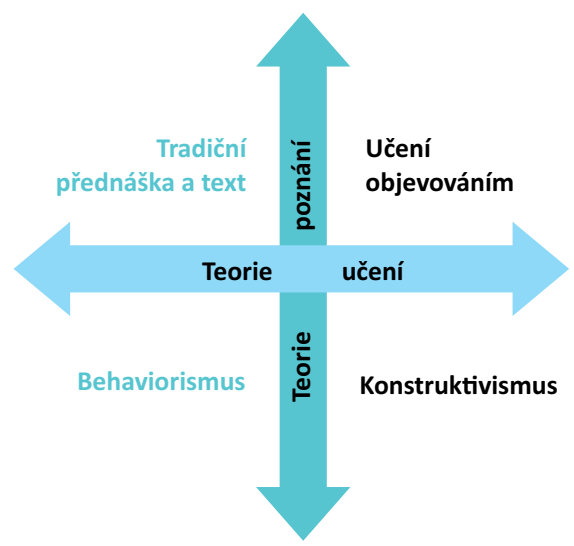

Hein, 1995

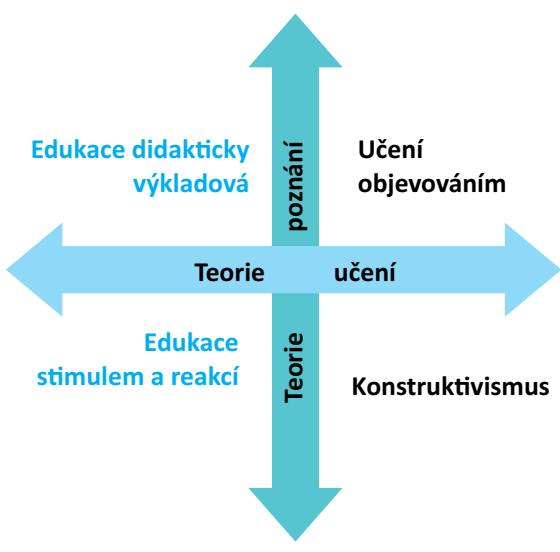

Hein, 1998

Obr. 2: Pedagogické teorie dle Heina v letech 1995 a 1998

Následně také aplikuje tyto čtyři typy teorií na muzejní praxi a popisuje čtyři typy realizace vzdělávání v muzeích.

Ve své monografii Learning in the Museum Hein věnuje kapitolu také pedagogickým teoriím. ${ }^{28}$ Obsahově se Hein v této kapitole nejvíce přibližuje ke článku z roku 1995, nicméně oproti němu jsou zde veškeré problémy rozpracovanější a přibývají i prvky nové. K teorii učení a teorii poznání autor přidává ještě teorii vyučování, kterou však nezahrnuje do svého pojetí dělení pedagogických teorií na čtyři hlavní skupiny. U těchto čtyř hlavních skupin se také objevují některé změny: skupina teorií behavioristických je zde popisněji označena jako edukace stimulem a reakcí a dříve rozvláčněji označované tradiční přednáška a text jsou v tomto případě přejmenovány na edukace didakticky výkladová (viz obr. 2).

28 HEIN, George E. Learning in the museum. London: Routledge, 1998, s. 14-41.
Obsah kategorií zůstává stejný jako $\mathrm{v}$ předchozím článku. V tomto textu se autor více obrací k autoritám pedagogických teorií a své uvažování zařazuje do kontextu jejich prací - a to jak autorů starších, tak soudobých. Celkově je text oproti předchozímu propracovanější, konkrétněji zavádí teorii do muzejní praxe i kontextu hlavního proudu pedagogické teorie.

Po rozpracování systému pedagogických teorií a jejich aplikace se Hein k tématu částečně vrací a zpřesňuje své pojetí konstruktivismu ve vztahu k pojmu vytváření významů, které považuje za součást konstruktivistického učení. ${ }^{29} \mathrm{~V}$ článku z roku 2001 se poté k upřesnění vztahu vrací a znovu zdůrazňuje, že konstruktivismus zahrnuje více než vytváření význa-

29 HEIN, George E. Is Meaning Making constructivism? Is Constructivism Meaning making? The Exhibionist, 1999, roč. 18, č. 2 s. $15-18$. mů v mysli učícího se jedince. ${ }^{30}$ Pojmem vytváření významů se autor zabývá do takové míry, že podle vztahu k tomuto termínu rozděluje pedagogické teorie do skupin ${ }^{31}$ (viz tab. 1).

V Heinově díle $\mathrm{v}$ daném období tak můžeme pozorovat vývoj od jednoduchého praktického přístupu v prvním článku, v němž pouze představuje pojem konstruktivismu a možnosti jeho vlivu na edukaci v muzeu široké muzejně pedagogické veřejnosti (ačkoliv již zde autor konstruktivismus obohacuje o své pojetí devíti principů konstruktivismu), přes rozpracování vlastního systému pedagogických teorií a vysvětlení dopadu jednotlivých teorií na muzejní edukaci až k postupnému upřesňování tohoto systému teorií, aby se autor nakonec opět vrátil pouze ke konstruktivistické teorii a vymezil ji ve vztahu k aktuálním pojmům rozvíjeným v současnosti v rámci pedagogických teorií.

\section{Potenciál Heinova díla pro sou- časný obecný pedagogický dis- kurz}

Korcová dle Hejného a Kuřiny (2000) a Novotného (2002) uvádí, že konstruktivismus ve výuce „... zajištuje takový prístup, kdy žák na základě vhodných podnětů a $v$ př́znivém klimatu třídy přistupuje aktivně $k$ vytváření vlastního myšlen-

30 HEIN, George E. Constructivism. More than Meaning Making. Museological Review, 2001, sv. 7, s. $1-17$.

31 HEIN, George E. Is Meaning Making constructivism? Is Constructivism Meaning making? The Exhibionist, 1999, roč. 18, č. 2, s. $15-18$. 
9 principů konstruktivismu (Hein, 1991)

1. Učení je aktivní proces

2. lidé se učí, jak se učit, když se učí

3. zásadní procesy probíhají v mysli subjektu

4. učení zahrnuje jazyk - jazyk, který se používá, ovlivňuje proces učení

5. učení je sociální

6. učení je kontextuální

7. lidé potřebují mít nějaké předchozí znalosti, aby se mohli dále učit

8. učení vyžaduje čas

9. motivace je při učení klíčová

\section{Charakteristické znaky konstruktivisticky pojatého vyučování (Murphy, 1997)}

- Zdůrazňuje se konstrukce znalostí a ne reprodukce.

- Cíle a plány pochází přímo od žáků nebo jsou stanoveny ve spolupráci s učitelem.

- Žáci aktivně sledují a řídí vlastní kognitivní činnost: vědí, ci umí, jak se to učí a proč.

- Klade se důraz na řešení problémů jako na didaktickou metodu, při které se zapojuje myšlení vyššího řádu a dochází k hlubokému porozumění.

- Učení je orientované na žáka, který je ve výuce hlavním činitelem.

- Individuální poznávání žáka se proměňuje díky vyjednávání, spolupráci a sociální zkušenosti: díky kooperativnímu učení.

- Učitel upřednostňuje koooperativní učení, aby žáci měli možnost vnímat alternativní názory: úkoly musí být takové, aby umožňovaly koopertivní činnosti.

- Učivo je předkládáno z různých hledisek, učitel využívá různých metod pro prezentaci učiva. - Primární data zprostředkovávají oodkaz na reálný svět a jeho souvislost s učivem.

- Žáci mají příležitost k „učňovskému učení“ (jednota praktických úkolů a rozvoje schopností a znalostí za pomoci učitele).

- Učební situace, techniky, obsah, a úkoly reprezentují přirozenou komplexnost reality světa - autentické činnosti odrážejí skutečné životní situace.

- Žákovy předchozí znalosti, domněnky, názory a stanoviska jsou zahrnuty do (re)konstrukčního procesu.

- Jendnota znalostí je reflektována $v$ zaměření na vztahy mezi známými pojmy a na mezipředmětové vztahy v souvislosti s novým učivem.

- Zkoumání je využíváno jako nejlepší přístup k povzbuzení žáků k nezávislému získávání znalostí a dosahování cílů.

- Žákům je poskytována pomoc při překonávání limitů svých schopností: podpůrné rozvíjející vyučování.

- Hodnocení je komplexní, předmětem je široké spektrum žákovských produktů.

- Chyba je respektována, zprostředkuje prríležitost pro vhled do žákových předchozích znalostí: s chybou se pracuje.

- Učitel je v roli kouče, mentora, průvodce, facilitátora a tutora, tedy toho, kdo vyučuje, pomáhá překonat obtíže, připravuje, naznačuje, poskytuje fakta. Učitel uplatňuje takový styl řízení, který je protipólem přikazování a kontroly.

Tab. 2: Konstruktivismus - principy a znaky

kového světa a rozvíjí své zkušenosti a představy prostřednictvím aktivit blízkých životu, objevováním a zkoumáním materiálů ze života přjímaného.“32

V roce 1997 zformulovala Elizabeth Murphy seznam projevů konstruktivistického př́istupu v praktickém vyučování. ${ }^{33} \mathrm{~V}$ následující tabulce

32 KORCOVÁ, Kateřina. Konstruktivismus v inovativních vzdělávacích programech v české škole. In Sborník prací filozofické fakulty brněnské univerzity. U11. Brno: Masarykova univerzita, 2006, s. 160 .

33 MURPHY, Elizabeth. Constructivist Checklist [online]. 1997 [cit. 2017-06-10]. Dostupný z www: <http://www.ucs.mun.ca/ emurphy/ stemnet/cle4.html >. V tabulce uvádíme překlad dle KORCOVÁ, Kateřina. Konstruktivismus porovnáme tuto syntézu s o šest let staršími devíti principy, jež Hein uvádí v prvním textu, kterým se v této práci zabýváme. ${ }^{34}$

Hein je tedy poměrně úspěšně schopen do svého systému devíti principů pojmout těchto 18 znaků konstruktivistického vyučování,

v inovativních vzdělávacích programech v české škole. In Sborník prací filozofické fakulty brněnské univerzity. U11. Brno: Masarykova univerzita, 2006, s. $159-168$.

34 HEIN, George E. Constructivist Learning Theory (CECA Conference: The Museum and the Needs of People, 15-22 October 1991, Jerusalem, Israel). In Exploratorium. Institute for Inquiry [online]. [cit. 2017-06-20]. Dostupný z www: $<$ https://www.exploratorium.edu/education/ifi/ constructivist-learning $>$. Př́íspěvek na konferenci. ačkoli body Hodnocení je komplexní, předmětem je široké spektrum žákovských produktů a Chyba je respektována, zprostředkuje príležitost pro vhled do žákových predchozích znalostí: $s$ chybou se pracuje, jsou s devátým principem spojeny spíše volně. Avšak je třeba uvést, že Hein ve své monografii upozorňuje na to, že konstruktivistické vyučování vyžaduje, aby závěry, k nimž učící se jedinci docházejí, nebyly posuzovány podle toho, zda se shodují s nějakým vnějším standardem toho, co je správné. Závěry je dle Heina třeba posuzovat na základě toho, zda vyhovují logickému přemýšlení na základě vstupních dat, 
a tak vlastně nelze hovořit o chybě, nýbrž o naivním konceptu. $\mathrm{O}$ chybě či omylu lze hovořit pouze, pokud závěry nekorespondují se vstupními daty. ${ }^{35}$ Zajímavé je, že charakteristiky konstruktivistického vyučování tak, jak zde byly uvedeny, nenaplňují Heinovy principy: učení zahrnuje jazyk - jazyk, který se používá, ovlivňuje proces učení a učení vyžaduje čas.

V současnosti se setkáváme s praktickým využíváním konstruktivismu zejména $\mathrm{v}$ didaktice matematiky, přírodních věd nebo dějepisu, ${ }^{36}$ často se také pedagogové zabývají potenciálem konstruktivismu pro e-learning ${ }^{37}$ a celoživotní učení. ${ }^{38}$ Samostatnou otázkou je poté vzdělávání pedagogů v konstruktivistické teorii. ${ }^{39}$

Pokud muzejní pracovníci vycházejí z konstruktivistické teorie, pak se tato skutečnost specificky odráží zejména v muzejně výstavní činnosti. Konstruktivistická výstavní forma bude mít mnoho vstupních bodů, nebude specifikována doporučená trasa ani nebude mít jasný začátek a konec, bude obsahovat prvky umožňující aktivní zapojení návštěvníků a nabízet více úhlů pohledu a propojí návštěvníky s představovanými exponáty prostřednictvím aktivit a zážitků, které budou navazovat na jejich předchozí život-

35 HEIN, George E. Learning in the museum. London: Routledge, 1998, s. 38.

36 STUCHLÍKOVÁ, Iva, Tomáš JANÍK, Zdeněk BENEŠ et al. Oborové didaktiky: vývoj, stav, perspektivy. Brno: Masarykova univerzita, 2015, s. 302.

37 ŠVAŘÍČEK, Roman a Klára ŠEĎOVÁ. Konstruktivismus v e-learningové vysokoškolské výuce? (Constructivism in E-learning at University-Level Teaching?). In Sborník prací filozofické fakulty brněnské univerzity. U12. Brno: Masarykova univerzita, 2007, s. 189-195.

38 ILLERIS, Knud. Contemporary theories of learning: learning theorists -- in their own words. New York: Routledge, 2009, s. 147-158.

39 Reflection of Constructivist Theories in Current Educational Practice. Universal Journal of Educational Research [online]. 2015, roč. 3, č. 5, s. 345-349 [cit. 2017-05-23]. Dostupný z www: $<$ http://www.hrpub.org/journals/article_info. php?aid $=2580>$. ní zkušenosti. ${ }^{40}$ Tato aplikace může být opět zajímavým podnětem pro učení skrze nová média a např́íklad e-learning.

\section{ZÁVĚREM}

$\mathrm{V}$ předloženém textu popisujeme konstruktivistickou teorii George E. Heina na př́ikladu článků z období mezi lety 1991-2001 a uvádíme ji do souvislosti s díly dalších autorů zabývajících se tímto teoretickým proudem. Ve studii se nám podařilo identifikovat Heinovo pojetí konstruktivismu nejdřive jako čistě kognitivní, v pozdějších letech propojuje přístupy kognitivního a sociálního konstruktivismu.

V kontextu současného uvažování o konstruktivismu se ukazuje, že Heinův přístup, ačkoliv na poli muzejní pedagogiky, má zajisté význam i pro obecný pedagogický diskurz. Již jeho devět principů konstruktivismu, které definoval $\mathrm{v}$ jednom z prvních článků zabývajících se konstruktivismem $\mathrm{v}$ muzeu, dokážou nejen pojmout, ale i obohatit uvažování o konstruktivistickém vyučování. Stejně tak si můžeme všimnout, že do svého teoretického systému zapracovává pojmy, které jsou aktuální v soudobém teoretickém uvažování. Jako príklad uved’me práci s pojmem vytváření významů na přelomu tisíciletí a jeho umístění do středu konstruktivistické teorie.

Jak se ukazuje, může být pro pedagogy prínosem, pokud se budou zajímat také o teorii a praxi realizovanou mimo školní prostředí. Muzejní pedagogika přináší zajímavé podněty zejména, pokud se zajímáme o objektové učení, jež je pro učení v muzeu typické, a učení skrze nová média.

40 HEIN, George E. Learning in the museum. London: Routledge, 1998, s. 39-41.

\section{SEZNAM POUŽITÝCH ZDROJŮ A LITERATURY:}

BERTRAND, Yves. Soudobé teorie vzdělávání. Praha: Portál, 1998. Studium. ISBN 80-717-8216-5.

HEIN, George E. Constructivism. More than Meaning Making. Museological Review, 2001, sv. 7, s. 1-17. ISSN 1354-5825.

HEIN, George E. Constructivist Learning Theory (CECA Conference: The Museum and the Needs of People, 15-22 October 1991, Jerusalem, Israel). In Exploratorium. Institute for Inquiry [online]. [cit. 2017-06-20]. Dostupný z www: <https://www.exploratorium. edu/education/ifi/constructivistlearning $>$. Příspěvek na konferenci.

HEIN, George E. The Constructivist museum. (Journal for Education in Museums, 1995, no. 16, s. 21-23). In Group of Education in Museums [online]. 1995 [cit. 2017-06-20]. Dostupný z www: <http://www.gem.org.uk/pubs/news/ hein1995.php $>$.

HEIN, George E. Is Meaning Making constructivism? Is Constructivism Meaning making? The Exhibionist, 1999, roč. 18 , č. 2 , s. 15-18.

HEIN, George E. Learning in the museum. London: Routledge, 1998. 203 s. Museum meanings. ISBN 04-150-9776-2.

HEIN, George E. Progressive museum practice: John Dewey and democracy. Walnut Creek, Calif.: Left Coast Press, 2012. 254 p. ISBN 978-161-1327-878.

ILLERIS, Knud. Contemporary theories of learning: learning theorists -- in their own words. New York: Routledge, 2009. ISBN 04-154-7343-8.

JAGOŠOVÁ, Lucie. Evaluace v muzejní edukaci - teoretická východiska. Museologica Brunensia, 2013, roč. 2, č. 2, 15-21. ISSN 1805-4722.

JAGOŠOVÁ, Lucie, Vladimír JŮVA a Lenka MRÁZOVÁ. Muzejní pedagogika: metodologické a didaktické aspekty muzejní edukace. Brno: Paido, 2010. ISBN 978-80-7315-207-9.

KORCOVÁ, Kateřina. Konstruktivismus $\mathrm{v}$ inovativních vzdělávacích programech v české škole. In Sborník prací filozofické fakulty brněnské univerzity. U11. Brno: Masarykova univerzita, 2006, s. 159168. ISBN 80-210-4143-9. 
MURPHY, Elizabeth. Constructivist Checklist [online]. 1997 [cit. 2017-06-10]. Dostupný z www: <http://www.ucs. mun.ca/ emurphy/stemnet/cle4.html>. PRŮCHA, Jan, Jiří MAREŠ a Eliška WALTEROVÁ. Pedagogický slovník. 2. rozš. a přeprac. vyd. Praha: Portál, 1998. ISBN 80-7178-252-1.

Reflection of Constructivist Theories in Current Educational Practice. Universal Journal of Educational Research [online]. 2015, roč. 3, č. 5, s. 345-349 [cit. 2017-05-23]. Dostupný z www: <http:// www.hrpub.org/journals/article_info. php?aid $=2580>$. ISSN 2332-3205. DOI: 10.13189/ujer.2015.030506.

STUCHLÍKOVÁ, Iva, Tomáš JANÍK, Zdeněk BENEŠ et al. Oborové didaktiky: vývoj, stav, perspektivy. Brno: Masarykova univerzita, 2015. ISBN 978-80-2107769-0.

STRÁNSKÝ, Zbyněk. Úvod do studia muzeologie. Brno: Masarykova univerzita, 2000. ISBN 80-210-1272-2.

ŠOBÁŇOVÁ, Petra. Edukační potenciál muzea. Olomouc: Univerzita Palackého v Olomouci, 2012. ISBN 978-80-244-3034-8.

ŠVAŘíČEK, Roman a Klára ŠEĎOVÁ. Konstruktivismus v e-learningové vysokoškolské výuce? (Constructivism in E-learning at University-Level Teaching?). In Sborník prací filozofické fakulty brněnské univerzity. U12. Brno: Masarykova univerzita, 2007, s. 189-195. ISBN 978-80-210-4472-2.

\section{MONIKA MIKULÁŠKOVÁ}

\section{Muzeum Brněnska,}

Česká republika

m.mikulaskova@muzeumbrnenska.cz

Absolventka muzeologie na Filozofické fakultě Masarykovy univerzity. V současné době pracuje jako muzejní pedagog v Muzeu Brněnska, kde spravuje muzejněpedagogické činnosti šesti poboček této instituce.

Studied museology at the Faculty of Arts, Masaryk University. She works as a museum educator in the Museum of the Brno Region where she is responsible for museum pedagogy activities of six branches of this institution. 